\title{
Genetic analysis of flower colour variation in Allium schoenoprasum L. (wild chives)
}

\author{
J. P. Stevens* and \\ S. M. Bougourd
}

Department of Biology, University of York, York YO1 5DD, U.K.

Genetic analysis of three naturally occurring flower colour variants of Allium schoenoprasum revealed the involvement of three diallelic loci in the control of flower colouration: $W / w$ controls the presence/absence of pigment, $D / d$ controls the distribution of pigment in the tepals (perianth segments), and $P / p$ controls pigment hue. There is no evidence of linkage between the three loci.

\section{INTRODUCTION}

Flower colour variants are found relatively frequently in species that have anthocyanin pigmentation (Kay, 1982). Allium schoenoprasum L. (wild chives) is no exception. The flowers of this species are normally purple, but occasional white flowered plants have been reported from populations in Europe (Stearn, 1980) and Canada (Scoggan, 1978).

During studies of the population cytogenetics and breeding behaviour of $A$. schoenoprasum in Europe, four white flowered plants and one of each of two further flower colour variants (designated pink and purple-tip) were found. The white and pink morphs occurred in a total sample of 1477 adult plants that were randomly collected, outside the flowering season, from 8 sites in Britain and 10 in continental Europe; the purple-tip morph was found among a large number of plants that were raised by D.S. Holmes from seeds and seedlings collected from the Wye valley (Powys, Wales). The low frequency of flower colour variants in the samples suggests that, in these populations at least, such forms are the result of recurrent mutation and are probably not maintained by natural selection. The only population that may be an exception is from near Tintagel (Cornwall, England), because four of the 96 plants sampled from this site were white flowered.

\footnotetext{
* Present address: Department of Botany and Microbiology, University College of Swansea, Singleton Park, Swansea SA2 8PP, U.K.
}

Flower colour variants that show simple Mendelian inheritance provide genetic markers which are useful in studies of the breeding system. The following is a report of the genetic analysis of purple-tip, pink and white flowered morphs of $\boldsymbol{A}$. schoenoprasum.

\section{MATERIALS AND METHODS}

\section{Description of flower colour morphs}

Purple Tepals and tepal veins purple (occasionally tepal veins green in plants from the population near Tintagel); anthers pink or purple (except for occasional male sterile plants which have yellow anthers). This is the standard flower colour morph.

Purple-tip Apical half to third of each tepal and tepal vein purple, basal parts white and green respectively; anthers pink or purple.

Pink Tepals light pink; tepal veins green or purple; anthers white.

White Tepals and anthers white; tepal veins pale green (occasionally greenish-purple in plants from Tintagel).

There is a subtle, more or less continuous variation in the intensity of tepal colouration within each of the three pigmented morphs. In addition, the distribution of pigment in the tepals of pinks is occasionally patchy. Patchiness may be environmentally induced, because two plants scored as uniform pink in 1984 were rescored as patchy pink in 1985. 


\section{Breeding programme}

Five experimental cross-pollinations were carried out: crosses 1-3 were between different pairs of purple and white flowered plants, cross 4 was between a purple and a purple-tip morph, and cross 5 was between a purple-tip and a pink morph. All but one of the parental plants were also selfpollinated. The pink, purple-tip and three white flowered parents originated from Carreg Cennen (Dyfed, Wales), the Wye valley (Powys, Wales) and Tintagel (Cornwall, England) respectively. The purple flowered parents were randomly selected from the Tintagel and River Wye population samples.

The flowers on female parents were emasculated when in bud and isolated in porous cellophane bags prior to cross-pollination, which was achieved by gently rubbing two freshly dehisced anthers on to each receptive stigma. Self-pollinations were carried out in a similar manner, but omitting bud emasculation. F2 families were generated by either selfing or sib-mating the F1 plants.

\section{RESULTS AND CONCLUSIONS}

\section{Purple $\times$ white}

The six parental plants used in crosses 1-3 all bred true when selfed (table1), which suggests that they were homozygous at the locus or loci controlling flower colour, although admittedly three of the self families were small. The F1 plants from all three crosses were purple flowered, and in the F2 generation, purples and whites segregated in proportions that are not significantly different from 3:1 ratios (table1). It is concluded that pigment production is controlled by a single locus showing normal Mendelian inheritance, and that white is recessive to purple. This locus is designated "W", in accordance with the symbolism recommended by Grant $(1975,166)$. White flowered morphs are assigned the genotype $w w$, and coloured morphs $W$-.

\section{Purple $\times$ purple-tip}

The purple-tip parent, which was used in crosses 4 and 5 , bred true when selfed (table 1). The F1 plants of cross 4 were all purple, and in the F2 generation, purples and purple-tips segregated in a 3:1 ratio (table 1). Thus, it appears that the restriction of pigmentation to the tips of the tepals is controlled by a single recessive allele showing normal Mendelian inheritance. The locus controll- ing pigment distribution is termed " $\mathrm{D}$ ". Morphs in which pigment is restricted to the apical part of each tepal are assigned the genotype $d d$, and morphs with uniformly coloured tepals $D$-.

\section{Purple-tip $\times$ pink}

The purple-tip parent used in this cross bred true when selfed. The pink parent, however, segregated pinks and whites in a $3: 1$ ratio (table 1). This suggests that the pink parent was heterozygous at the locus controlling pigment production $(W w)$, and that it was homozygous at another locus causing pink rather than purple pigmentation. This locus is designated " $P$ ". Complementation occurred in cross 5 , all the $F 1$ plants being purple (table 1 ). Therefore, pink is recessive to purple, and pink morphs are assigned the genotype $p p$ and purple morphs PP. A new phenotype, which had tinges of pink restricted to the tips of the tepals and white anthers, appeared in the F2 generation of cross 5 . This phenotype is designated pink-tip, and assigned the genotype $W-d d p p$.

The F1 generation of cross 5 was expected to contain both $W W$ homozygotes and $W w$ heterozygotes. All but one of the F2 families segregated white flowered plants, and therefore clearly arose from heterozygous $W w$ parents. The expected number of each flower colour morph in this group of F2 families was calculated using a trihybrid ratio which was modified to account for the epistatic effect of the $w$ allele on the other colour genes. The one F2 family that did not segregate whites arose from a cross between two $F 1$ plants and contained 41 progeny. The probability that the parents of this family were both $W w$ heterozygotes is extremely low $\left(P=0 \cdot 75^{41}=7 \cdot 54 \times 10^{-6}\right)$. Therefore, it was assumed that at least one of the parents was a $W W$ homozygote, and the expected number of each flower colour morph in the F2 was calculated using a standard Mendelian dihybrid ratio. In neither group did the expected frequencies differ significantly from the observed, although the expected number of pink-tips in the group that did not segregate whites was rather low $(2 \cdot 6)$.

\section{DISCUSSION}

Biosynthetic pathways of pigment production in flowers often involve several steps that are controlled by different genes. In such cases, pigment production may be blocked by mutation occurring at one of several loci. For example, five different loci are involved in the control of flower 


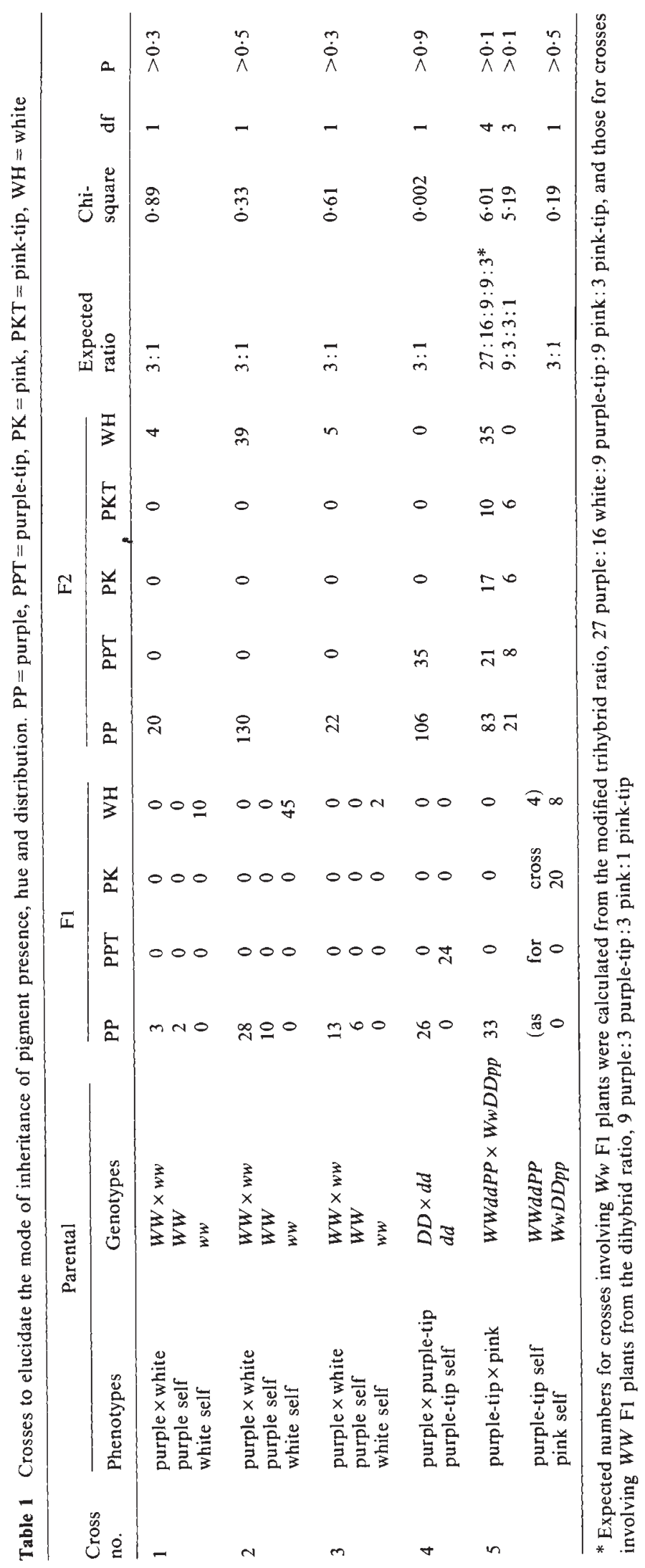


pigmentation in Antirrhinum majus (Harrison and Stickland, 1974; Stickland and Harrison, 1974), three genotypically different, but phenotypically white, morphs occur in Hyacinthoides non-scripta (Endymion non-scriptus) (Stickland and Harrison, 1977), and segregation at three different loci accounts for the 8 different flower colour phenotypes of Ipomoea purpurea (Ennos and Clegg, 1983). In Allium schoenoprasum, three diallelic loci involved in the control of flower colour have been identified $(W / w, P / p$ and $D / d)$. The possibilities that more loci, or additional alleles at these known loci, exist in natural populations cannot be ruled out. There is no evidence (from cross $5)$ of linkage between " $W$ ", " $D$ " and "P", and all three loci are suitable for use as genetic markers.

Acknowledgements We are grateful to Mrs S. Lewis for scoring flower colours in some experimental progenies, to Mr K. Partridge for help with maintaining the plants, and to Dr D. P. Stevens and Dr T. J. Crawford for their critical discussion and comments. The financial assistance of S.E.R.C. is gratefully acknowledged.

\section{REFERENCES}

ENNOS, R. A. AND CLEGG, M. T. 1983. Flower color variation in the morning glory, Ipomoea purpurea. J. Hered., 74, 247-250.

GRANT, V. 1975. Genetics of Flowering Plants. Columbia Univ. Press, New York.

HARRISON, B. J. AND STICKLAND, R. G. 1974. Precursors and genetic control of pigmentation. II. Genotype analysis of pigment controlling genes in acyanic phenotypes in Antirrhinum majus. Heredity, 33, 112-115.

KAY, Q. O. N. 1982. Intraspecific discrimination by pollinators and its role in evolution. In Armstrong, J. A., Powell, J. M. and Richards, A. J. (eds.) Pollination and Evolution, Royal Botanic Gardens, Sydney, pp. 9-28.

SCOGGAN, H. J. 1978. The Flora of Canada. Natl. Mus. Nat. Sci. Canada, Publ. Bot., 7, Ottawa.

Stearn, w. T. 1980. Allium L. In Tutin, T. G., Heywood, V. H., Burges, N. A., Moore, D. M., Valentine, D. H., Walters, S. M. and Webb, D. A. (eds.) Flora Europaea, Vol. 5, Cambridge Univ. Pres, Cambridge, pp. 49-69.

STICKLAND, R. G. AND HARRISON, B. J. 1974. Precursors and genetic control of pigmentation. I. Induced biosynthesis of pelargonidin, cyanidin and delphinidin in Antirrhinum majus. Heredity, 33, 108-112.

STICKLAND, R. G. AND HARRISON, B. J. 1977. Precursors and genetic control of pigmentation. III. Detection and distribution of different white genotypes of bluebells (Endymion species). Heredity, 39, 327-333. 